\title{
Ontogenetic changes in diet and habitat use in green sea turtle (Chelonia mydas) life history
}

\author{
Karen E. Arthur ${ }^{1,2, *}$, Michelle C. Boyle ${ }^{3}$, Colin J. Limpus ${ }^{4}$ \\ ${ }^{1}$ Centre for Marine Studies, University of Queensland, St Lucia, Queensland 4072 Australia \\ ${ }^{2}$ The Smithsonian Marine Station at Fort Pierce, 701 Seaway Dr, Fort Pierce, Florida 34949 USA \\ ${ }^{3}$ James Cook University, Townsville, Queensland 4811, Australia \\ ${ }^{4}$ Queensland Environmental Protection Agency, 160 Ann St, Brisbane, Queensland 4000 Australia
}

\begin{abstract}
Green turtles Chelonia mydas are endangered, long-lived marine reptiles that display an ontogenetic shift in diet and habitat use during development. During their early life stage, juvenile green turtles in the southwestern Pacific inhabit the pelagic zone where they feed omnivorously on neustonic material. At approximately $44 \mathrm{~cm}$ curved carapace length they recruit to inshore foraging habitats where they become primarily herbivorous. In this study we investigate the change in stable isotope $\left(\delta^{13} \mathrm{C}\right.$ and $\left.\delta^{15} \mathrm{~N}\right)$ composition of green turtle epidermal tissue throughout their life history to examine this ontogenetic shift in diet and habitat as it occurs in a southwestern Pacific green turtle population. Turtles that had recently recruited to foraging grounds in Moreton Bay, Australia had significantly higher $\delta^{15} \mathrm{~N}$ isotopic signatures when compared with all other life history groups examined and significantly lower $\delta^{13} \mathrm{C}$ when compared with all age classes other than pelagic juveniles. Adult and large immature turtles had similar isotopic signatures and were both significantly enriched in ${ }^{13} \mathrm{C}$ when compared with hatchlings and small immature turtles. These results support previous observations that suggest pelagic juveniles are foraging in a different habitat and at a higher trophic level than turtles captured in the neritic environment. This is the first study to capture the entire life history of green turtles in terms of foraging ecology and supports the ontogenetic shift previously observed in traditional diet and behavioral studies of green turtles.
\end{abstract}

KEY WORDS: Stable isotope analysis $\cdot$ Trophic shift $\cdot$ Chelonia mydas $\cdot \delta^{13} \mathrm{C} \cdot \delta^{15} \mathrm{~N} \cdot$ Green turtle Resale or republication not permitted without written consent of the publisher

\section{INTRODUCTION}

Green turtles Chelonia mydas (Linnaeus) are longlived marine reptiles that inhabit the tropical and subtropical oceans of the world. They have great ecological and cultural significance (Balazs et al. 1994, Frazier 2003), but, due to overharvesting, habitat loss and disease they are currently considered an endangered species by the International Union for the Conservation of Nature (IUCN 2007).

Green turtles have a unique and complex life history during which they display periods of extensive migration followed by extended periods in relatively small home ranges. Adult females have a short terrestrial phase during which they are thought to return to a beach in the region from which they themselves hatched to lay eggs (Carr 1982, Meylan et al. 1990). In the southwest Pacific Ocean, green turtle hatchlings have a pelagic phase of approximately 5 to $10 \mathrm{yr}$, during which they associate with pelagic currents and feed on neustonic material (Musick \& Limpus 1997). During this time they are known as pelagic juveniles, a life history phase that is often referred to as the 'lost years' as comparatively little is known about their biology and ecology due to their inaccessible nature (Carr 1982, Bolten 2003). Pelagic juvenile green turtles are thought to be primarily omnivorous, feeding on a range of planktonic material including crustaceans, jellyfish and ctenophores (Bolten 2003, Boyle 2007). In the southwestern Pacific oceanic environment pelagic juvenile green turtles grow to approximately $44 \mathrm{~cm}$ in curved carapace length (CCL) at which time they 
recruit to a neritic foraging habitat (Limpus et al. 2005). In some populations, green turtles recruit to a developmental habitat prior to moving to an adult feeding ground (Bjorndal \& Bolten 1996). Once in an inshore feeding ground, green turtles often show high site fidelity to the region, returning to specific areas to forage, and generally only leaving as adults to make breeding migrations (Chaloupka et al. 2004, Limpus et al. 2005). The shift in habitat that occurs between pelagic juvenile green turtles and the later life stages is accompanied by a change in feeding behavior that entails a shift from an omnivorous diet of neustonic material to one of predominant herbivory, consisting of macroalgae, seagrass and/or mangrove material (Bjorndal 1997, Limpus \& Limpus 2000, Bolten 2003).

Stable isotope analysis has become a popular and powerful tool in ecological research particularly for determining trophic level, identifying major food sources and assessing migratory behavior in animals or life history stages that are otherwise cryptic or difficult to sample (Peterson \& Fry 1987, Hobson \& Clark 1992). Traditionally, animal diet studies have relied on direct observation and stomach content analysis and, in some cases, what remains in fecal material (see Bjorndal 1997). However, these techniques only provide a snapshot of what the animal has consumed in recent feeding events (Levey \& Martinez del Rio 2001). Dietary inference from stable isotope analysis of animal tissue is possible because animal tissue isotopic composition is ultimately derived from that of its complete diet over time (DeNiro \& Epstein 1978, 1981).

The ratio of stable carbon $\left({ }^{13} \mathrm{C}:{ }^{12} \mathrm{C} ; \delta^{13} \mathrm{C}\right)$ and nitrogen $\left({ }^{15} \mathrm{~N}:{ }^{14} \mathrm{~N} ; \delta^{15} \mathrm{~N}\right)$ isotopes in tissue have proved useful in nutritional studies as they undergo predictable changes in the ratio of heavier to lighter isotope abundance (discrimination) as a result of chemical, biological and physical processes (DeNiro \& Epstein 1978, 1981, Tieszen et al. 1983, Peterson \& Fry 1987). Stable nitrogen isotopes $\left(\delta^{15} \mathrm{~N}\right)$ are altered during metabolism as ${ }^{15} \mathrm{~N}$ is preferentially retained in the body during excretion, causing the $\delta^{15} \mathrm{~N}$ of animal tissue to generally be 3 to $5 \%$ onriched from its food source (DeNiro \& Epstein 1981, Minagawa \& Wada 1984). There is a progressive enrichment of ${ }^{15} \mathrm{~N}$ with increasing trophic level making $\delta^{15} \mathrm{~N}$ measurements useful indicators of an animal's trophic level (DeNiro \& Epstein 1981, Minagawa \& Wada 1984, Peterson \& Fry 1987). Carbon isotopic ratios provide an indication of the animal's habitat as it generally reflects diet isotopic ratio more closely than $\delta^{15} \mathrm{~N}$ and is typically only $\sim 1 \%$ enriched from prey (DeNiro \& Epstein 1978, Rau et al. 1983). As a result, investigating an animal's $\delta^{13} \mathrm{C}$ signature can be used in tracing its food source where large variation exists in the isotopic signature of food sources. Within marine systems, $\delta^{13} \mathrm{C}$ variation exists between inshore benthic food webs and offshore pelagic food webs, with the former having higher $\delta^{13} \mathrm{C}$ values than the latter (Rau et al. 1983, Rubenstein \& Hobson 2004). An animal's $\delta^{13} \mathrm{C}$ signature may also indicate the latitude at which it has been foraging as $\delta^{13} \mathrm{C}$ values in phytoplankton (bottom of the marine food chain) are more depleted at higher latitudes than those nearer the equator (Rau et al. 1982). As such, the combination of nitrogen and carbon isotopic ranges can provide geographical and trophic status information regarding foraging ecology and resource acquisition in green turtles.

There are 2 fundamental aspects to the successful application of stable isotope analysis in ecological studies. The first is an understanding of the discrimination value for the stable isotopic signature of interest as this varies between species and with tissue type (Tieszen et al. 1983, Minagawa \& Wada 1984, Seminoff et al. 2006). Because the discrimination value for both $\delta^{13} \mathrm{C}$ and $\delta^{15} \mathrm{~N}$ have been determined in laboratory studies of green turtle epidermis tissue (Seminoff et al. 2006), it is possible to assess potential green turtle diet items by comparing epidermal tissue signatures, in light of discrimination values, with that of potential diet items. The second is establishing the elemental turnover time in tissues of interest, or the period of time that tissue isotopic value reflects that of diet. As elemental turnover occurs in metabolically active tissues, the stable isotopic signature of the tissue will change with time. The rate of change will vary with tissue type as tissues with high turnover rate, such as liver or plasma, will reflect recent diet while tissues with slower turnover, such as epidermis or feathers, reflect longer-term dietary changes (Hobson \& Clark 1993, Gannes et al. 1997). The only study to assess tissue turnover rates in reptiles was conducted on freshwater pond sliders Trachemys scripta (Seminoff et al. 2007) and, given the metabolic differences associated with osmoregulation (Bentley 1976), these values cannot be extrapolated to marine turtles. However, it is anticipated that epidermal tissue will provide medium- to long-term dietary information as it demonstrates relatively slow turnover in other organisms (Tieszen et al. 1983, Hobson \& Clark 1992, Seminoff et al. 2007).

Only a handful of studies have utilized stable isotope analysis in marine turtle ecology. These include the assessment of the trophic status of green turtles relative to loggerhead turtles (Godley et al. 1998); the identification of foraging grounds for turtles nesting in Japan (Hatase et al. 2002, Hatase et al. 2006); the effect of diving physiology on bone isotopic composition in green, leatherback and olive ridley turtles (Biasatti 2004) and the identification of differences in nitrogen cycling regimes in oceanic basins based on leatherback isotopic signatures (Wallace et al. 2006). As noted 
above, Seminoff et al. (2006) described differential discrimination between tissue types in immature green turtles and Reich et al. (2007) used carbon and nitrogen isotopic signature of green turtle scutes to identify habitats and diet of pelagic juveniles in the Atlantic Ocean.

Although ontogenetic shifts in both habitat and diet have been described in green turtle life history using traditional diet studies, in-water research and behavioral observations (Musick \& Limpus 1997, Bolten 2003), prey-derived nutrients have not been examined in the earlier life history stages of green turtles. This study assesses changes in the feeding ecology of green turtles throughout their life history using $\delta^{13} \mathrm{C}$ and $\delta^{15} \mathrm{~N}$ analysis of epidermal tissue. We address life history changes in habitat and diet and examine the rate of change in $\delta^{13} \mathrm{C}$ and $\delta^{15} \mathrm{~N}$ signatures after ontogenetic life history changes in wild green turtles.

\section{MATERIALS AND METHODS}

Epidermal tissue was collected for stable isotope analysis from 64 green turtles representing 5 life history stages (Table 1). All of the turtles sampled were captured in southeast Queensland, Australia between 2002 and 2005. Hatchlings from 4 separate mothers were sampled by collecting 8 eggs (2 from each mother) from the Wreck Rock rookery $\left(151^{\circ} 58^{\prime} \mathrm{E}\right.$, $\left.24^{\circ} 19^{\prime} \mathrm{S}\right)$, which were incubated at 29.0 to $30.5^{\circ} \mathrm{C}$ with hatchlings sampled upon emergence. Nine pelagic juveniles (curved carapace length $(\mathrm{CCL})=6.6$ to $23.5 \mathrm{~cm}$ ) were sampled during necropsy procedures after they washed up dead on southern Queensland beaches. These turtles were deemed 'pelagic juveniles' based on carapace measurements. The remaining 47 samples $(\mathrm{CCL}=41.1$ to $115.0 \mathrm{~cm}$ ) were collected

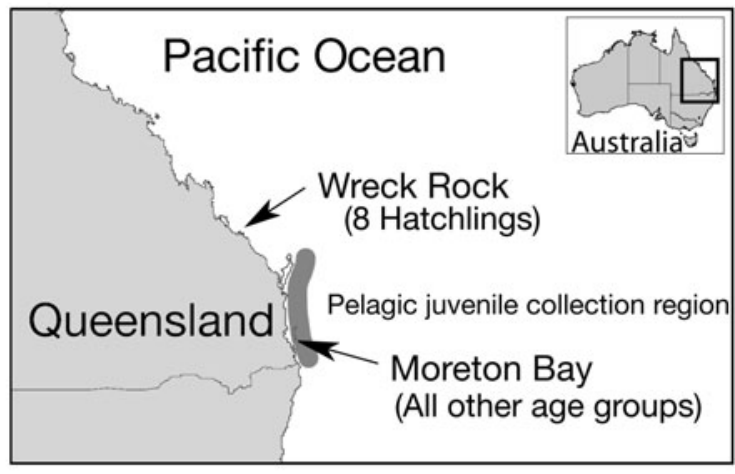

Fig. 1. Stable isotope sample collection locations in Queensland, Australia. Eight eggs (from 4 adult females) were collected from Wreck Rock rookery. Beach-washed dead pelagic juveniles were collected between Fraser Island and the Gold Coast (grey region) and all other life history stages were captured alive in the inshore feeding habitat of Moreton Bay

from live turtles captured in the Moreton Bay foraging ground $\left(153^{\circ} 23^{\prime} \mathrm{E}, 27^{\circ} 22^{\prime} \mathrm{S}\right)$ during an ongoing population demographic study (C. J. Limpus unpubl.) (Fig. 1). The turtles were tagged and measured in accordance with the Queensland Turtle Conservation Project's protocol (Limpus et al. 1994) and their sex and maturity (immature/mature) was determined based on laparoscopic gonad examination (Miller \& Limpus 2003, Limpus et al. 2005). For data analysis, the sampled turtles were divided into life history stages: hatchling, pelagic juvenile, immature and adult (sexually mature). Pelagic juvenile turtles were divided into small $(\mathrm{CCL}<10 \mathrm{~cm})$ and large $(\mathrm{CCL}>10 \mathrm{~cm})$ categories to differentiate recently hatched turtles from those that had been in the pelagic environment for some month. It should be noted that no turtles of CCL range 23.6 to $40.0 \mathrm{~cm}$ were encountered during this study. The class 'immature' consisted of all animals

Table 1. Chelonia mydas. Capture location, epidermal tissue sampling location and average curved carapace length (CCL) of each life history group of turtles sampled for stable isotope analysis

\begin{tabular}{|c|c|c|c|c|c|}
\hline Life history stage & Habitat & Location & Skin sample & $\mathrm{n}$ & Mean CCL $(\mathrm{cm})$ \\
\hline Hatchlings & Terrestrial & Wreck Rock Rookery & Hind flipper & 8 & $4.9^{\mathrm{a}}$ \\
\hline \multicolumn{6}{|l|}{ Pelagic juveniles } \\
\hline Large $(\mathrm{CCL}<10 \mathrm{~cm})$ & Pelagic & Fraser Island to Gold Coast & Inguinal & 7 & 7.5 \\
\hline Small (CCL > 10 cm) & & & & 2 & 21.8 \\
\hline \multicolumn{6}{|l|}{ Immature turtles $(\mathrm{CCL}<65 \mathrm{~cm})$} \\
\hline New recruits & Neritic & Morton Bay & Inguinal & 14 & 43.8 \\
\hline Known years since recruitment & & & & 9 & 51.5 \\
\hline Unknown years since recruitment & & & & 6 & 52.8 \\
\hline Immature turtles $(\mathrm{CCL}>65 \mathrm{~cm})$ & Neritic & Moreton Bay & Inguinal & 8 & 84.4 \\
\hline Mature turtles & Neritic & Moreton Bay & Inguinal & 10 & 108.5 \\
\hline Total & & & & & 64 \\
\hline
\end{tabular}


captured in the foraging area that were not mature. For the purposes of analysis, this group was further refined to small $(\mathrm{CCL}<65 \mathrm{~cm}$ ) and large $(\mathrm{CCL}>$ $65 \mathrm{~cm})$, with new recruits assigned to the former category. New recruits were identified by the presence of a clean white plastron with obvious ventral ridges that had not yet been worn down by abrasion in an inshore area. These physical observations indicate a turtle has been in the neritic habitat for just a few months (Limpus et al. 2005). As the Moreton Bay green turtle population has been studied for >16 yr (Limpus et al. 1994, Chaloupka et al. 2004), the number of years since recruitment from the pelagic to coastal environment was known for 9 immature animals sampled during this study.

Epidermal tissue was collected from the ventral inguinal region above the hind flipper in all turtles, except the hatchlings, using the methods outlined by Dutton \& Balazs (1995). The skin on the dorsal side of the inguinal region of a hind flipper was scraped clean to remove any ectoparasitic material and a thin layer of epidermal tissue $\left(\sim 1 \mathrm{~cm}^{2}\right)$ was collected using a scalpel. As hatchling turtles were too small for this sample collection technique, a small section of epidermal tissue was instead removed from the trailing edge of a hind flipper. All tissue samples were immediately frozen and maintained at $-4^{\circ} \mathrm{C}$ pending stable isotope analyses.

Skin samples were dried at $60^{\circ} \mathrm{C}$ for approximately $48 \mathrm{~h}$ prior to stable isotope analysis $\left(\delta^{13} \mathrm{C}\right.$ and $\left.\delta^{15} \mathrm{~N}\right)$ using the Dumas combustion technique (Coleman \& Fry 1991). Stable isotope analysis was undertaken at Griffith University Stable Isotope Analysis Laboratory using an Isoprime (GV Instruments) coupled to a EuroVector EA 3000 elemental analyzer.

In one instance where a turtle was found stranded dead in Moreton Bay during the study period, food items were removed from the turtle's crop and analyzed as per skin samples to provide a comparison with epidermal tissue. These items included 2 species of seagrass $(n=2)$, an unidentified jellyfish $(n=1)$ and mangrove fruit $(\mathrm{n}=1)$.

All results are presented as the mean \pm SD. Statistical analysis was undertaken using SigmaStat 3.11 (Systat Software). One-way ANOVA was used to compare $\delta^{13} \mathrm{C}$ and $\delta^{15} \mathrm{~N}$ between life history stages. Where a significant difference was found amongst the groups a Tukey's HSD was employed to compare differences in isotopic signatures between life stages. A Student's $t$-test was used to assess differences in isotopic ratio between small and large pelagic juveniles. As with previous studies, the pattern of change in stable isotope $\left(\delta^{13} \mathrm{C}\right.$ and $\left.\delta^{15} \mathrm{~N}\right)$ epidermal tissue in turtles with known time since recruitment resembled an exponential model (see Fig. 3). As such we fitted equations to our data of the form $Y=Y_{0}+a \exp (-b t)$ where $Y_{0}$ represents initial isotopic value, $a$ and $b$ are derived constants, and $t$ is the time since recruitment, or hypothesized change in diet (Hobson \& Clark 1992, Hobson \& Bairlein 2003, Ogden et al. 2004).

\section{RESULTS}

Epidermal tissue was collected from 64 green turtles from 5 separate life history stages, including 9 turtles with known years since recruitment (Table 1). Tissue

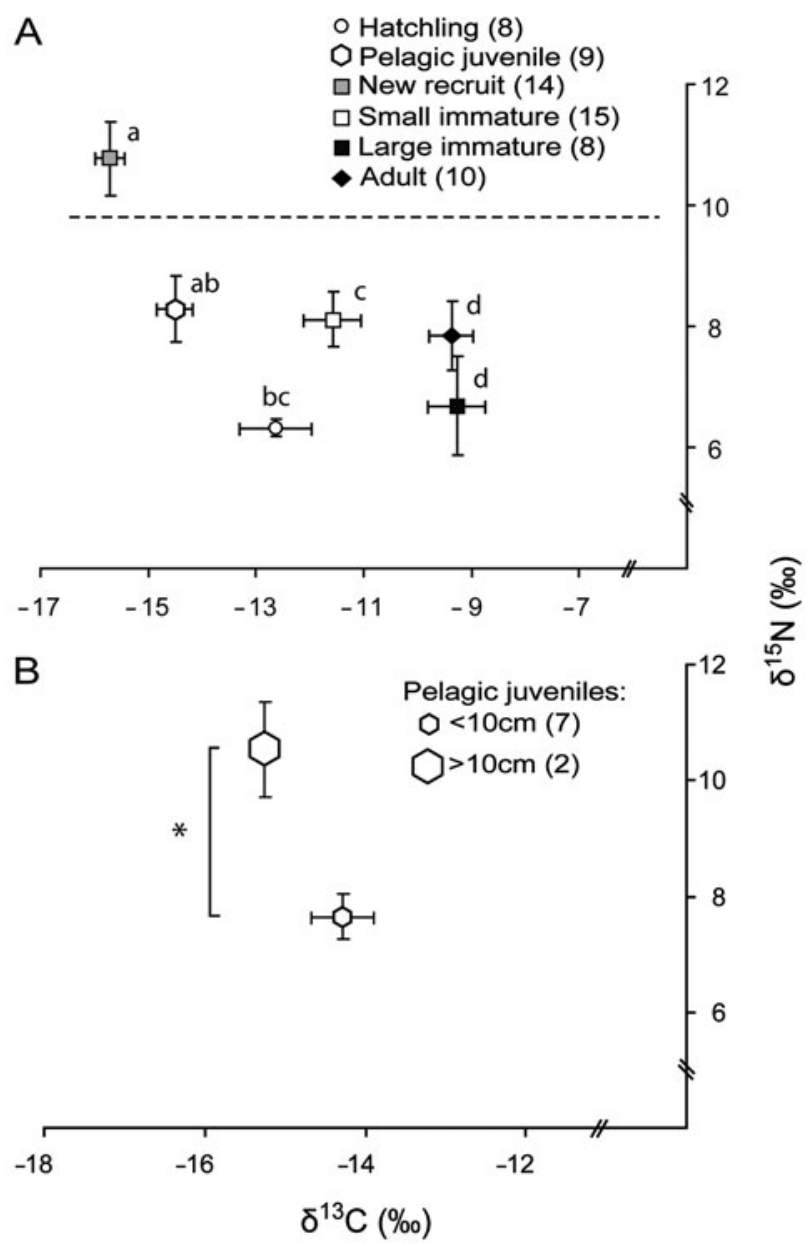

Fig. 2. Chelonia mydas. Stable $\delta^{13} \mathrm{C}$ and $\delta^{15} \mathrm{~N}$ values for green turtle epidermal tissue of different life history groups. The number of samples in each life history group is provided in brackets. Data are provided as mean values with one standard error represented by error bars. (a) All life history groups sampled during this study (ANOVA $\left(\delta^{13} \mathrm{C}\right): F=31.914$, df $=5$, $\left.\mathrm{p}<0.001 ;\left(\delta^{15} \mathrm{~N}\right): F=8.150, \mathrm{df}=5, \mathrm{p}<0.001\right)$. Differences between groups based on Tukey's HSD are denoted by letters for $\delta^{13} \mathrm{C}$ and a dashed horizontal line for $\delta^{15} \mathrm{~N}$. (b) Pelagic juvenile life history group separated into small $(<10 \mathrm{~cm}$ CCL) and large ( $>10 \mathrm{~cm} \mathrm{CCL})$ individuals $\left(t\right.$-test $\left(\delta^{13} \mathrm{C}\right): t=1.294, \mathrm{df}=7$, $\left.\mathrm{p}=0.237 ;\left(\delta^{15} \mathrm{~N}\right): t=-3.374, \mathrm{df}=7, \mathrm{p}=0.012\right)$. *Significant differences between groups 
Table 2. Chelonia mydas. Carbon and nitrogen stable isotopic signature of green turtle epidermal tissue from each life history stage given as the mean (SD) and range

\begin{tabular}{|c|c|c|c|c|c|}
\hline \multirow[t]{3}{*}{ Life stage } & \multirow[t]{3}{*}{$\mathrm{n}$} & \multicolumn{4}{|c|}{ Epidermal stable isotopic signature } \\
\hline & & \multicolumn{2}{|c|}{$\delta^{13} \mathrm{C}(\%)$} & \multicolumn{2}{|c|}{$\delta^{15} \mathrm{~N}(\%)$} \\
\hline & & Mean & Range & Mean & Range \\
\hline Hatchling & 8 & $-12.6(1.9)$ & -15.0 to -10.3 & $6.3(0.4)$ & 5.7 to 6.8 \\
\hline Small pelagic juvenile & 7 & $-14.3(1.0)$ & -15.8 to -12.6 & $7.6(1.0)$ & 6.6 to 9.2 \\
\hline Large pelagic juvenile & 2 & $-15.3(0.0)$ & -15.3 to -15.2 & $10.5(1.2)$ & 9.7 to 11.4 \\
\hline New recruit & 14 & $-15.7(1.0)$ & -16.8 to -13.3 & $10.8(2.3)$ & 6.8 to 14.7 \\
\hline New recruit +1 yr & 1 & -15.3 & & 12.7 & \\
\hline New recruit $+2 \mathrm{yr}$ & 2 & $-12.8(1.2)$ & -13.6 to -11.9 & $8.0(3.6)$ & 5.5 to 10.5 \\
\hline New recruit $+3 \mathrm{yr}$ & 3 & $-11.4(0.6)$ & -12.1 to -10.9 & $8.0(0.4)$ & 7.5 to 8.2 \\
\hline New recruit $+4 \mathrm{yr}$ & 1 & -10.1 & & 8.6 & \\
\hline New recruit $+7 \mathrm{yr}$ & 1 & -9.7 & & 7.0 & \\
\hline New recruit $+8 \mathrm{yr}$ & 1 & -12.4 & & 8.0 & \\
\hline Immature $<65 \mathrm{~cm}^{\mathrm{a}}$ & 6 & $-11.1(2.6)$ & -16.2 to -9.3 & $7.5(1.1)$ & 5.9 to 8.4 \\
\hline Immature $>65 \mathrm{~cm}$ & 8 & $-9.3(1.5)$ & -11.6 to -7.5 & $6.7(2.3)$ & 4.8 to 11.5 \\
\hline Adult & 10 & $-9.4(1.3)$ & -12.2 to -7.9 & $7.8(1.8)$ & 6.0 to 12.0 \\
\hline
\end{tabular}

isotopic signatures of $\delta^{13} \mathrm{C}$ and $\delta^{15} \mathrm{~N}$ values varied significantly among life history classes (ANOVA $\left(\delta^{13} \mathrm{C}\right)$ : $F=31.914, \mathrm{df}=5, \mathrm{p}<0.001 ;$ ANOVA $\left(\delta^{15} \mathrm{~N}\right): F=8.150$, $\mathrm{df}=5, \mathrm{p}<0.001$ ) (Fig. 2a). A Tukey's HSD showed new recruits to be significantly different from all other groups based on $\delta^{15} \mathrm{~N}$ signature, and different from all groups except pelagic juveniles based on $\delta^{13} \mathrm{C}$ signatures (Table 2, Fig. 2a). Adults and large immature turtles were not significantly different from one another in terms of $\delta^{13} \mathrm{C}$, however, they both differed significantly from other life history groups in terms of epidermal $\delta^{13} \mathrm{C}$ values (Fig. 2a). Hatchlings collected from the Wreck Rock rookery had $\delta^{13} \mathrm{C}$ isotopic signatures that were significantly depleted when compared with adults and large immature turtles, as did small juvenile turtles captured in Moreton Bay; however, small immature and hatchling turtles did not differ significantly from one another (Fig. 2a). Pelagic juveniles were significantly depleted in ${ }^{13} \mathrm{C}$ when compared with immature and adult turtles, but not when compared with hatchlings and new recruits. Within the pelagic juvenile group, $\delta^{13} \mathrm{C}$ signatures did not differ between the large $(>10 \mathrm{~cm}$ CCL) and small $(<10 \mathrm{~cm}$ CCL) turtles ( $t$-test: $t=1.294, \mathrm{df}=7, \mathrm{p}=0.237$ ) (Fig. $2 \mathrm{~b}$ ); however, large pelagic juveniles were significantly enriched in ${ }^{15} \mathrm{~N}$ when compared with the smaller pelagic juveniles ( $t$-test: $t=-3.374, \mathrm{df}=7, \mathrm{p}=0.012$ ) (Table 2, Fig. 2b).

Recently recruited turtles to the inshore feeding habitat had significantly depleted ${ }^{13} \mathrm{C}(-15.7 \%$ vs. $-11.2 \%$ o) and enriched ${ }^{15} \mathrm{~N}$ (10.8\%o vs. 7.5\%) tissue isotopic signatures when compared with other small immature turtles of unknown time since recruitment, even though all turtles were captured in the neritic foraging ground

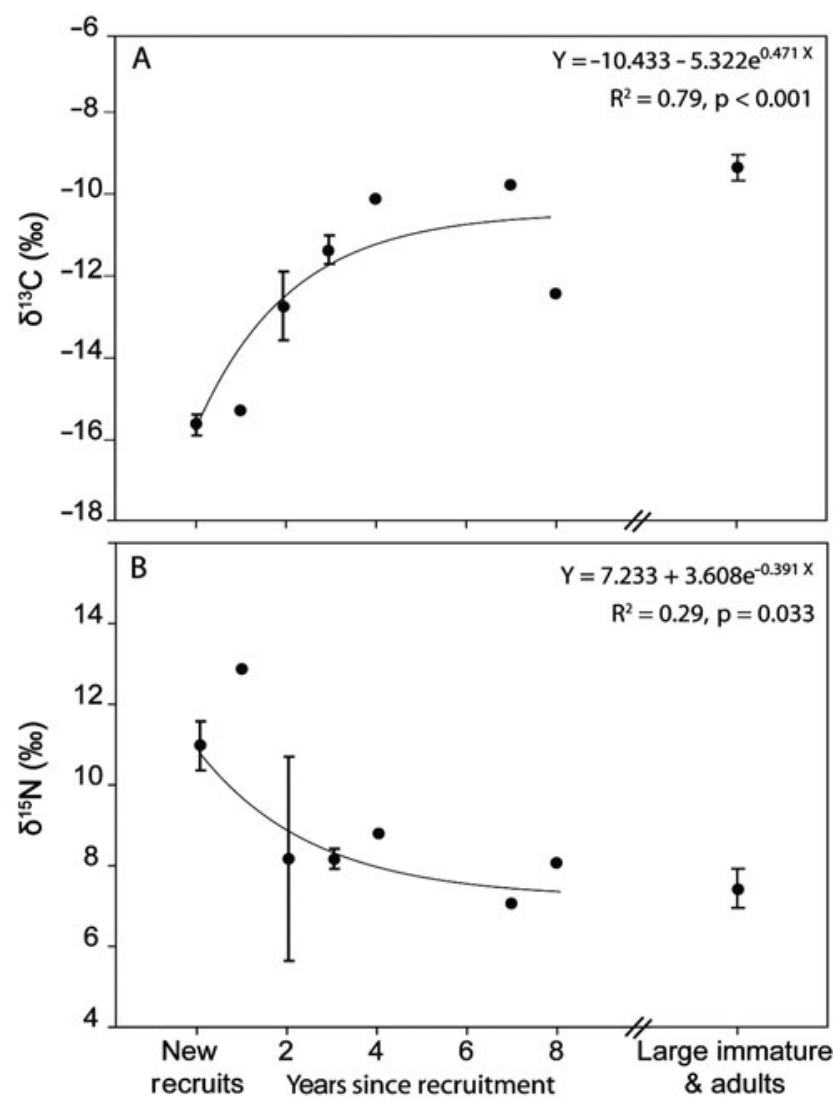

Fig. 3. Chelonia mydas. Non-linear regression analysis for stable isotopic signatures of epidermal tissue from small immature turtles with known years post recruitment $(n=23)$ for $(\mathrm{a})$ $\delta^{13} \mathrm{C}$ and (b) $\delta^{15} \mathrm{~N}$. Isotopic signatures are also provided for large immature and adult turtles for reference, but these were not included in the regression analysis, as years post regression are not known for these individuals. Values are mean $\pm \mathrm{SE}$ 
(Table 2, Fig. 2a). There was a significant exponential relationship between the time since recruitment and the isotopic composition of epidermal tissue in turtles with known time since recruitment (non-linear regression: $\mathrm{p}<0.05$ ) (Fig. 3). The longer turtles had been resident in the neritic foraging area, the more their epidermal isotopic signatures approached that of large immature and adult turtles (Fig. 3).

\section{DISCUSSION}

Carbon and nitrogen stable isotope composition of green turtle epidermal tissue varies significantly with life history stage. The $\delta^{15} \mathrm{~N}$ signature of new recruits is significantly enriched when compared with other age groups (Fig. 2a), suggesting that they occupy a higher trophic level than other life history groups (Minagawa $\&$ Wada 1984). In addition, the $\delta^{13} \mathrm{C}$ of new recruits is significantly lower when compared with all other age groups except the pelagic juveniles (Fig. 2a), and very similar to the $\delta^{13} \mathrm{C}$ signature of the large pelagic juveniles (Table 2). This suggests that both these groups obtain nutrients for tissue production from locations outside the neritic foraging area. Although the new recruits were captured in the Moreton Bay foraging ground, their epidermal isotopic signature probably represents feeding regimes of pelagic juveniles, as the new recruits have only been in the neritic foraging area for a few months (Limpus et al. 2005). Pelagic juveniles are difficult to study as they are rarely encountered, particularly the largest size classes of this life history stage (Bolten 2003). Here the new recruits provide a proxy for this group, as their epidermal stable isotopic signatures are unlikely to have changed substantially in the few months they have been resident in the neritic foraging ground. As such, this study supports previous observations that suggest pelagic juvenile turtles are found in a different habitat and are consuming different diet items from the larger longterm residents in the Moreton Bay foraging ground (Bolten 2003). These results also support the findings of Reich et al.'s (2007) study in the Bahamas where microlayers of scute punches were analyzed for $\delta^{15} \mathrm{~N}$ and $\delta^{13} \mathrm{C}$ signatures to assess the changes in diet of green turtles recruiting from Atlantic oceanic habitat to inshore seagrass habitats. Analysis of successive layers of scute tissue revealed a shift in both $\delta^{15} \mathrm{~N}$ and $\delta^{13} \mathrm{C}$ from oldest to newest tissues with the oldest layers, and therefore those laid down whilst the turtle was in the pelagic habitat, having higher $\delta^{15} \mathrm{~N}$ value and lower $\delta^{13} \mathrm{C}$ values than newer tissue signatures (Reich et al. 2007). Together these studies confirm that, even in separate genetic populations of green turtles, pelagic juveniles feed at a higher trophic level and in a different geographic location from that of other life history stages.

Whereas life history stages other than new recruits did not differ significantly in terms of $\delta^{15} \mathrm{~N}$ signatures, $\delta^{13} \mathrm{C}$ values were significantly different between these groups (Fig. 2a). Adults and large immature turtles that were captured whilst foraging in Moreton Bay had similar epidermal isotopic signatures indicating that: (1) they had been foraging in a similar area for an extended period of time, an observation supported by long-term tag recoveries of turtles feeding in this population (Limpus et al. 1994, Chaloupka et al. 2004); and (2) they employ a similar feeding strategy. Given discrimination factors of approximately $+2.8 \%$ and $+0.17 \%$ for $\delta^{15} \mathrm{~N}$ and $\delta^{13} \mathrm{C}$ respectively in green turtle epidermal tissue (Seminoff et al. 2006), it is likely that these turtles were feeding predominantly on seagrass (Tables 2 \& 3), as has been observed in mouth and dietary stomach lavage samples (K.E.L. \& C.J.L. pers. obs.).

As newly hatched green turtles derive their energy from the egg yolk provided by their mother, it was anticipated that hatchling turtles would have a similar isotopic signature to that of the adults, with potentially a trophic increase indicated by higher $\delta^{15} \mathrm{~N}$ values as the hatchlings 'consume' the yolk (Hobson 1995). However, this was not the case in the current study (Fig. 2a). Hatchling turtles collected from Wreck Rock had similar $\delta^{15} \mathrm{~N}$ signatures, but significantly depleted ${ }^{13} \mathrm{C}$, when compared with adult turtles from the Moreton Bay foraging habitat. As the mothers' origin(s) were unknown, it is feasible that the hatchlings' mothers may have come from foraging areas other than Moreton Bay, such as coral reef habitats where green turtles feed predominantly on macroalgae instead of seagrass (Forbes 1994). Foraging outside of Moreton Bay could influence isotopic composition in 2 ways. If the turtles were consuming a similar seagrass-based diet as those in Moreton Bay, but were foraging at higher latitudes, it is likely their $\delta^{13} \mathrm{C}$ signature would be depleted compared with those of Moreton Bay (Rau et al. 1982, Rubenstein \& Hobson 2004). However, as Moreton Bay is essentially the southern limit of green turtle foraging (Limpus et al. 1994), it is unlikely this is the cause of the hatchlings' lower $\delta^{13} \mathrm{C}$ signature. Alternatively, if the adult turtles resided in an area where their diet was dominated by macroalgae, their epidermal $\delta^{13} \mathrm{C}$ signature would be lower than those foraging predominantly on seagrass (Table 3 ). Without a greater understanding of stable isotopic discrimination during yolk production and hatchling development, it is difficult to draw ecological conclusions regarding the relationship between mothers and offspring in this study. Future research using stable isotopes in green turtles would benefit greatly from 
Table 3. Carbon and stable isotopic signatures of potential food sources for green sea turtles as reported in the literature. Data are presented as the range of the mean values presented in the literature

\begin{tabular}{|c|c|c|c|c|}
\hline Food source & Location & $\delta^{13} \mathrm{C}(\%)$ & $\delta^{15} \mathrm{~N}(\%)$ & Source \\
\hline Seagrass & Moreton Bay & -15.4 to -6.6 & 2.2 to 8.6 & $\begin{array}{l}\text { Grice et al. (1996), Udy \& Dennison (1997), } \\
\text { Connolly (2003), Guest et al. (2004), } \\
\text { Carseldine \& Tibbetts (2005), Melville \& } \\
\text { Connolly (2005), this study }\end{array}$ \\
\hline Macroalgae & Moreton Bay & -19.8 to -17.0 & 4 to 7.9 & Connolly (2003), Guest et al. (2004) \\
\hline Mangrove & Moreton Bay & -29.0 to -22.5 & 0.7 to 5.8 & $\begin{array}{l}\text { Melville \& Connolly (2003), Werry \& Lee (2005), } \\
\text { this study }\end{array}$ \\
\hline Zooplankton & Japan \& Moreton Bay & -21.3 to -14.1 & 4.8 to 16.3 & Takai et al. (2000), Hatase et al. (2002), this study \\
\hline
\end{tabular}

studies of known mother-offspring pairs to establish discrimination between parent and offspring and between egg components and resulting tissue types. A further challenge in comparing hatchling isotopic signatures with that of other life stages is that, due to the small size of the hatchlings, it was not feasible to take skin samples from the inguinal region. Samples were instead taken from the skin at the end of one of the hind flippers, and it is possible that this small difference in sampling location may have impacted isotopic results.

Epidermal isotopic composition of pelagic juveniles was not significantly different from hatchling turtles in either $\delta^{15} \mathrm{~N}$ or $\delta^{13} \mathrm{C}$ (Fig. 2a). However, this sample group was composed mainly of small $(<10 \mathrm{~cm}$ CCL) turtles and, as such, they are thought not to have been in the pelagic environment, and therefore had not been feeding independently, for very long. In contrast, the large pelagic juveniles, whilst only having a small sample size $(n=2)$, did demonstrate a significant shift in epidermal $\delta^{15} \mathrm{~N}$ signatures (Fig. 2b). This indicates that they had been feeding at a higher trophic level, or on diet items with higher $\delta^{15} \mathrm{~N}$ value, than the small pelagic juveniles. As such, they provide a link to the new recruits which we suggest represent the foraging strategies of elusive pelagic juveniles that have been in the pelagic environment for multiple years and were not sampled in this study.

This study was able to incorporate a small number of turtles with known years since recruitment and, as such, explore the time it takes for stable isotopic signatures of epidermal tissue to reflect that of long-term residents after a shift in habitat and diet. The sample size of this group, and the fact that these turtles are wild with natural variation in their diets, prevents defenitive conclusions being drawn regarding turnover rate in green turtles from this data. However, it is interesting to consider changes in isotopic signature during a natural dietary shift from that of a pelagic omnivore to an inshore primarily herbivorous forager. Both $\delta^{13} \mathrm{C}$ and $\delta^{15} \mathrm{~N}$ demonstrate a significant exponen- tial relationship between time since recruitment and isotopic signature (Fig. 3). Turtles that had been in the foraging grounds longer had higher $\delta^{13} \mathrm{C}$ and lower $\delta^{15} \mathrm{~N}$ values when compared with new recruits, and $\delta^{15} \mathrm{~N}$ signatures quickly approached those of long-term residents (Fig. 3b), while $\delta^{13} \mathrm{C}$ values appear to take longer. Although differential incorporation rates have been described for $\mathrm{C}$ and $\mathrm{N}$ and they cannot be assumed to be equal (Hobson \& Bairlein 2003, Reich et al. 2007), there may also be ecological reasons for this difference in $\delta^{13} \mathrm{C}$ and $\delta^{15} \mathrm{~N}$ change through time (Fig. 3). It is possible that pelagic juveniles do not make a defined dietary shift upon recruitment and instead have a transitional stage during which they supplement their diet with a greater proportion (relative to older life history stages) of macroalgae and mangrove material, both of which have lower $\delta^{13} \mathrm{C}$ values than seagrass, but similar $\delta^{15} \mathrm{~N}$ values (Table 3 ). In support of this hypothesis, substantial quantities of both these items have been observed in diets of immature turtles from Moreton Bay (Brand-Gardner et al. 1999, Read \& Limpus 2002), while larger age classes have been observed to predominantly consume seagrass (K.E.A. \& C.J.L. pers. obs.). If the small immature turtles are consuming more macroalgae and mangrove material than larger individuals, then the observed lower $\delta^{13} \mathrm{C}$ values may indicate that turtles in their first few years inhabiting a foraging ground may inhabit a slightly different niche from that of the larger turtles within the one feeding ground. This is further supported by behavioral observations of smaller turtles generally being found in shallower habitats and amongst mangroves where more macroalgae is available, while larger individuals inhabit deeper channels and access deeper seagrass beds (Limpus et al. 2005). Developmental habitats have been described in Florida where small turtles initially recruit to an inshore feeding area and then move on to an adult foraging habitat (Bjorndal \& Bolten 1996). In Florida, these habitats are distinct areas, but it is possible that a similar process may be occurring in Moreton Bay with habitat partitioning 
occurring within the same geographic region and turtles of different sizes utilizing different habitat niches. To fully understand the ecological implications of the isotopic results observed here, controlled studies of turnover rate in turtles of differing life history stages and diet types are required (Gannes et al. 1997).

This is the first study to investigate the stable isotopic composition of green turtle epidermal tissue across all primary life history stages. Stable isotopic data collected in this study supports previous behavioral observations and traditional feeding studies in that green pelagic juvenile turtles in this western Pacific population undergo an ontogenetic shift as they recruit from the pelagic ocean habitat to an inshore feeding area. This shift is evident in the stable isotope composition of epidermal tissue with a distinct shift from a signature that is representative of an open ocean omnivorous dietary source to an inshore herbivorous source. Additionally, the results from this study suggest niche partitioning amongst turtles of different life history stages within one foraging habitat. However, controlled laboratory experiments are needed to clarify fractionation and turnover rates in different tissue types under varying environmental conditions and in different aged turtles to more fully appreciate the limits of inference that may be placed on field data.

Acknowledgements. This work was conducted in conjunction with the Queensland Turtle Research Project (QTRP) and was funded in part by: Seaworld Research and Rescue Foundation Inc., Queensland, Australia; Queensland Government Smart State Funding Program; Queensland Environmental Protection Agency (EPA); and the Great Barrier Reef Marine Park Authority (GBRMPA). The authors thank the QTRP volunteers for their efforts in capturing, handling and sampling turtles and D. Limpus and S. Hermanussen for the collection of samples for this project. This research was conducted under the animal ethics permits: BOT/450/01/QPWS/QTRP/UQP; the South Queensland Animal Experimentation Ethics Committee, Project 10; the GBRMPA/State Marine Parks Permit G00/240. Symbols used in diagrams were courtesy of the Integration and Application Network (www.ian.umces.edu/ symbols), University of Maryland Center for Environmental Science. The authors thank K. Reich, M. Clementz and 3 anonymous reviewers for their valuable comments on this manuscript.

\section{LITERATURE CITED}

Balazs GH, Dudley WC, Hallacher LE, Coney JP, Koga S (1994) Ecology and cultural significance of sea turtles at Punalu'u, Hawaii. In: Bjorndal KA, Bolten AB, Johnson DA, Eliazar PJ (eds) Proc 14th Annu Symp Sea Turtle Biol Cons, Miami, FL. NOAA Tech Memo NMFS-SEFSC 351, p 10-13

Bentley PJ (1976) Osmoregulation in reptiles. In: Gans C, Dawson WR (eds) Biology of the reptilia. Academic Press, New York, p 365-412

Biasatti D (2004) Stable carbon isotopic profiles of sea turtle humeri: implications for ecology and physiology. Palaeogeogr Palaeoclimatol Palaeoecol 206:203-216

Bjorndal KA (1997) Foraging ecology and nutrition of sea turtles. In: Lutz PL, Musick JA (eds) The biology of sea turtles. CRC Press, London, p 199-231

Bjorndal KA, Bolten AB (1996) Developmental migrations of juvenile green turtles in the Bahamas. In: Keinath JA, Barnard DE, Musick JA, Bell BA (eds) Proc 14th Annu Symp Sea Turtle Biol Cons, Miami, FL. NOAA Tech Memo NMFS-SEFSC 387, p 38

Bolten AB (2003) Variation in sea turtle life history patterns: neritic vs. oceanic development stages. In: Lutz PL, Musick JA, Wyneken J (eds) The biology of sea turtles, Vol II. CRC Press, Washington, DC, p 243-257

Boyle MC (2007) Post-hatchling sea turtle biology. PhD dissertation, James Cook University, Townsville, Australia

Brand-Gardner SJ, Lanyon JM, Limpus CJ (1999) Diet selection by immature green turtles, Chelonia mydas, in subtropical Moreton Bay, south-east Queensland. Aust J Zool 47:181-191

Carr A (1982) Notes on the behavioral ecology of sea turtles. In: Bjorndal KA (ed) Biology and conservation of sea turtles, Vol I. Smithsonian Institute Press, Washington, DC, p 19-26

Carseldine L, Tibbetts IR (2005) Dietary analysis of the herbivorous hemiramphid Hyporhamphus regularis ardelio: an isotopic approach. J Fish Biol 66:1589-1600

Chaloupka M, Limpus C, Miller J (2004) Green turtle somatic growth dynamics in a spatially disjunct Great Barrier Reef metapopulation. Coral Reefs 23:325-335

Coleman DC, Fry B (eds) (1991) Carbon isotope techniques. Academic Press, San Diego, CA

> Connolly RM (2003) Differences in trophodynamics of commercially important fish between artificial waterways and natural coastal wetlands. Estuar Coast Shelf Sci 58: 929-936

DeNiro MJ, Epstein S (1978) Influence of diet on the distribution of carbon isotopes in animals. Geochim Cosmochim Acta 42:495-506

DeNiro MJ, Epstein S (1981) Influence of diet on the distribution of nitrogen isotopes in animals. Geochim Cosmochim Acta 45:341-351

Dutton P, Balazs GH (1995) Simple biopsy techniques for sampling skin for DNA analysis of sea turtles. Mar Turtle News 69:9-10

Forbes GA (1994) The diet of the green turtle in an algalbased coral reef community-Heron Island, Australia. In: Schroeder BA, Witherington BE (eds) Proc 13th Annu Symp Sea Turtle Biol Cons, Jekyll Island, GA. NOAA Tech Memo NMFS-SEFSC-341, p 57-59

Frazier J (2003) Prehistoric and ancient historic interactions between humans and marine turtles. In: Lutz PL, Musick JA, Wyneken J (eds) The biology of sea turtles, Vol II. CRC Press, London, p 1-38

Gannes LZ, O'Brien DM, Martinez del Rio C (1997) Stable isotopes in animal ecology: assumptions, caveats, and a call for more laboratory experiments. Ecology 78:1271-1276

Godley BJ, Thompson DR, Waldron S, Furness RW (1998) The trophic status of marine turtles as determined by stable isotope analysis. Mar Ecol Prog Ser 166:277-284

> Grice AM, Loneragan NR, Dennison WC (1996) Light intensity and the interactions between physiology, morphology and stable isotope ratios in five species of seagrass. J Exp Mar Biol Ecol 195:91-110

Guest MA, Connolly RM, Loneragan NR (2004) Within and among-site variability in $\delta \mathrm{C}^{13}$ and $\delta \mathrm{N}^{15}$ for three estuarine producers, Sporobolus virginicus, Zostera capricorni, and 
epiphytes of Z. capricorni. Aquat Bot 79:87?94

Hatase H, Takai N, Matsuzawa Y, Sakamoto W and others (2002) Size-related differences in feeding habitat use of adult female loggerhead turtles Caretta caretta around Japan determined by stable isotope analyses and satellite telemetry. Mar Ecol Prog Ser 233:273-281

- Hatase H, Sato K, Yamaguchi M, Takahashi K, Tsukamoto K (2006) Individual variation in feeding habitat use by adult female green sea turtles (Chelonia mydas): Are they obligate neritic herbivores? Oecologia 149:52-64

> Hobson KA (1995) Reconstructing avian diets using stable carbon and nitrogen isotope analysis of egg components: patterns of isotopic fractionation and turnover. Condor 97: $752-762$

Hobson KA, Bairlein F (2003) Isotopic fractionation and turnover in captive golden warblers (Sylvia borin): implications for delineating dietary and migratory association in wild passerines. Can J Zool 81:1630-1635

Hobson KA, Clark RG (1992) Assessing avian diets using stable isotopes I: turnover of $\delta C^{13}$ in tissue. Condor 94 : 181-188

Hobson KA, Clark RG (1993) Turnover of ${ }^{13} \mathrm{C}$ in cellular and plasma fractions of blood: implications for nondestructive sampling in avian diet studies. Auk 110:638?641

IUCN (2007) The IUCN red list of threatened species. Available at www.iucnredlist.org

> Levey DJ, Martinez del Rio C (2001) It takes guts (and more) to eat fruit: lessons from avian nutritional ecology. Auk 118:819-831

Limpus CJ, Limpus DJ (2000) Mangroves in the diet of Chelonia mydas in Queensland, Australia. Mar Turtle News 89: $13-15$

Limpus CJ, Fleay AF, Guinea M (1984) Sea turtles of the Capricorn section, Great Barrier Reef. In: Ward WT, Saenger P (eds) The Capricornia section of the Great Barrier Reef: past, present and future. Royal Society of Queensland and Australian Coral Reef Society, Brisbane, p 61-78

Limpus CJ, Couper PJ, Read MA (1994) The green turtle, Chelonia mydas, in Queensland: population structure in a warm temperate feeding area. Mem Qld Mus 35:139-154

Limpus CJ, Limpus DJ, Arthur KE, Parmenter CJ (2005) Monitoring of green turtle population dynamics in Shoalwater Bay: 2000-2004. Research Publication No. 83, Great Barrier Reef Marine Park Authority Research Publication Series, Townsville

Melville AJ, Connolly RM (2003) Spatial analysis of stable isotope data to determine primary sources of nutrition for fish. Oecologia 136:499-507

Melville AJ, Connolly RM (2005) Food webs supporting fish over subtropical mudflats are based on transported organic matter not in situ microalgae. Mar Biol 148: $363-371$

Meylan AB, Bowen BW, Avise JC (1990) A genetic test of the natal homing versus social facilitation models for green turtle migration. Science 248:724-727

Miller JD, Limpus CJ (2003) Ontogeny of marine turtle gonads. In: Lutz PL, Musick JA, Wyneken J (eds) The biol-

Editorial responsibility: Otto Kinne,

Oldendorf/Luhe, Germany ogy of sea turtles, Vol II. CRC Press, Washington, DC, p 199-225

Minagawa M, Wada E (1984) Stepwise enrichment of ${ }^{15} \mathrm{~N}$ along food chains: further evidence and the relationship between $\delta \mathrm{N}^{15}$ and animal age. Geochim Cosmochim Acta 48:1135-1140

Musick JA, Limpus CJ (1997) Habitat utilization and migration in juvenile sea turtles. In: Lutz PL, Musick JA (eds) The biology of sea turtles, Vol 1. CRC Press, Washington, DC, p 137-163

Ogden LJ, Hobson KA, Lank DB (2004) Blood isotopic $\left(\delta C^{13}\right.$ and $\delta \mathrm{N}^{15}$ ) turnover and diet-tissue fractionation factors in captive dunlin (Calidris alpina pacifica). Auk 121:170-177

> Peterson BJ, Fry B (1987) Stable isotopes in ecosystem studies. Annu Rev Ecol Syst 18:293-320

- Rau GH, Sweeney RE, Kaplan IR (1982) Plankton ${ }^{13} \mathrm{C}:{ }^{12} \mathrm{C}$ ratio changes with latitude: differences between northern and southern oceans. Deep-Sea Res 29:1035-1039

Rau GH, Mearns AJ, Young DR, Olson RJ, Schafer HA, Kaplan IR (1983) Animal C/C correlates with trophic level in pelagic food webs. Ecology 64:1314-1318

Read MA, Limpus CJ (2002) The green turtle, Chelonia mydas, in Queensland: feeding ecology of immature turtles in Moreton Bay, southeastern Queensland. Mem Qld Mus 48:207-214

Reich KJ, Bjorndal KA, Bolten AB (2007) The 'lost years' of green turtles: using stable isotopes to study cryptic life stages. Biol Lett 3:712-714

> Rubenstein DR, Hobson KA (2004) From birds to butterflies: animal movement patterns and stable isotopes. Trends Ecol Evol 19:256-263

> Seminoff JA, Jones TT, Eguchi T, Jones DR, Dutton PH (2006) Stable isotope discrimination $\left(\delta \mathrm{C}^{13}\right.$ and $\left.\delta \mathrm{N}^{15}\right)$ between soft tissue of the green sea turtle Chelonia mydas and its diet. Mar Ecol Prog Ser 308:271-278

> Seminoff JA, Bjorndal KA, Bolten AB (2007) Stable carbon and nitrogen isotope discrimination and turnover in pond sliders Trachemys scripta: insights for trophic study of freshwater turtles. Copeia 534-542

Takai N, Onaka S, Ikeda Y, Yatsu A, Kidokoro H, Sakamoto W (2000) Geographical variations in carbon and nitrogen stable isotope ratios in squid. J Mar Biol Assoc UK 80: 675-684

Tieszen LL, Boutton TW, Tesdahl KG, Slade NA (1983) Fractionation and turnover of stable carbon isotopes in animal tissues: implications for $\delta^{13} \mathrm{C}$ analysis of diet. Oecologia 57: 32-37

> Udy JW, Dennison WC (1997) Growth and physiological response of 3 seagrass species to elevated sediment nutrients in Moreton Bay, Australia. J Exp Mar Biol Ecol 217: 253-277

> Wallace BP, Seminoff JA, Kilham SS, Spotila JR, Dutton PH (2006) Leatherback turtles as oceanographic indicators: stable isotope analyses reveal a trophic dichotomy between ocean basins. Mar Biol 149:953-960

- Werry J, Lee SY (2005) Grapsid crabs mediate link between mangrove litter production and estuarine planktonic food chains. Mar Ecol Prog Ser 293:165-176

Submitted: May 29, 2007; Accepted: February 4, 2008

Proofs received from author(s): June 6, 2008 